\title{
PEGAS ELASTIS BERBASIS SIG PADA JENJANG SMA/SMK KABUPATEN SUMEDANG
}

\author{
${ }^{1}$ Yan Yan Sofiyan, ${ }^{2}$ Muhammad Agreindra Helmiawan, ${ }^{3}$ Dody Herdiana \\ ${ }^{1}$ yanyan@stmik-sumedang.ac.id, ${ }^{2}$ agreindra@ stmik-sumedang.ac.id, ${ }^{3}$ dody@ stmik- \\ sumedang.ac.id
}

\begin{abstract}
Abstrak
Proyek perubahan optimalisasi mutu layanan pendidikan ini berisikan sejumlah tahapan yang bertujuan untuk menata dan menempatkan guru dalam memberikan layanan pendidikan kepada para siswa pada jenjang pendidikan menengah. Hal ini memicu pengembangan sistem ICT dalam pemetaan guru antar sekolah dengan teknologi sederhana yang dapat dilakkukan oleh satuan pendidikan, sesuai dengan tuntutan kurikulum yang dikembangkan berdasarkan KTSP maupun kurikulum Tahun 2013 (K-13). Untuk itu dalam penelitian ini dikembangkan sebuah sistem informasi geografis dengan pemanfaatan geolocation yang bertujuan untuk menampilkan peta digital beserta lokasi penyebaran guru jenjang menengah pada Dinas Pendidikan Kab. Sumedang secara elaboratif, aspiratif, sistemik, transfaran dan terintegrasi.
\end{abstract}

Kata kunci: sistem informasi geografis (SIG), geolocation, node.js, pemetaan, google maps

\begin{abstract}
The project to change the optimization of the quality of education services contains a number of stages that aim to organize and place teachers in providing education services to students in secondary education. This has triggered the development of ICT systems in the inter-school teacher mapping with simple technology that can be carried out by education units, in accordance with the demands of the curriculum developed based on the KTSP and 2013 curriculum (K-13). For this reason in this study a geographical information system was developed with the use of geolocation which aims to display digital maps along with the location of the distribution of secondary level teachers in the District Education Office. Sumedang is elaborative, aspirational, systemic, transparent and integrated.
\end{abstract}

Keywords: geographic information system (GIS), geolocation, node.js, mapping, google maps 


\section{PENDAHULUAN}

Proyek perubahan optimalisasi mutu layanan pendidikan ini berisikan sejumlah tahapan yang bertujuan untuk menata dan menempatkan guru dalam memberikan layanan pendidikan kepada para siswa pada jenjang pendidikan menengah meliputi SMA dan SMK di lingkungan Dinas Pendidikan dan Kebudayaan Kab. Sumedang, secara terpadu, terbuka dan sistemik, sebagai bagian integral dari upaya peningkatan mutu layanan pendidikan yang telah diprogramkan pemerintah.

Kondisi saat ini, jumlah guru pada jenjang pendidikan menengah di lingkungan Dinas Pendidikan dan Kebudayaan Kab. Sumedang sebanyak: 2.786 orang, terdiri atas PNS sebanyak 882 orang dan Guru Bukan PNS (GBPNS) 1.904, tersebar di 100 sekolah, yaitu SMA sebanyak 24 sekolah dan SMK sebanyak 76 sekolah, meliputi negeri dan swasta. Adapun jumlah siswa seluruhnya sebanyak 35.908 orang, sehingga angka perbandingan diperoleh 1:13. Hal ini menujukkan kondisi guru pada jenjang pendidikan menengah belum mencapai angka perbandingan minimal yakni 1:20 untuk SMA dan 1:15 untuk SMK (PP No. 74 Tahun 2008).

Fenomena ini, memerlukan intervensi pemerintah Kab. Sumedang, khususnya Dinas Pendidikan dan Kebudayaan, dalam penataan tenaga guru antar sekolah, sehingga diharapkan dapat terciptanya pemerataan guru sesuai dengan tuntutan regulasi yang ada. Selama ini, penataa guru semata-mata berdasarkan pertimbangan sebatas satuan pendidikan, sedangkan antar satuan pendidikan belum tersedia fasilitas yang dapat menata penyebaran guru, secara proporsional.

Oleh karena itu, sebagai alternatif strategis untuk terciptanya profesionalisme guru, yang pada akhirnya dapat meningkatkan mutu layanan pendidikan pada jenjang pendidikan menengah meliputi SMA dan SMK pada Dinas Pendidikan dan Kebudayaan adalah dengan mengembangkan program pemetaan guru antar sekolah yang selanjutnya disingkat (PEGAS), melalui prinsip Elaborasi (kecermatan/ akurasi), Aspiratif (menampung/ menerima), Sistemis (saling terkait), Transfaran (terbuka) dan Terintegritas (utuh terpadu), disingkat (ELASTIS). Dengan demikian program ini dinamakan "PEGAS ELASTIS".

Maka dikembangkan sebuah aplikasi berbasis Sistem Informasi Geografis (SIG) dengan tujuan untuk memetakan lokasi penyebaran guru jenjang menengah pada Dinas Pendidikan Kab. Sumedang yang dapat dilakukan oleh satuan pendidikan, sesuai dengan tuntutan kurikulum yang dikembangkan berdasarkan KTSP maupun Kurikulum Tahun 2013 (K-13).

Sistem Informasi Geografis berbasis web sendiri merupakan sebuah sistem yang mempunyai data spasial atau koordinat yang kemudian diolah menjadi informasi dan pemetaan.

Kemampuan dasar Sistem Informasi Geografis yaitu mengintegrasikan berbagai operasi basis data seperti query, menganalisisnya serta menampilkannya dalam bentuk pemetaan berdasarkan letak geografisnya. Inilah yang membedakan SIG dengan sistem informasi lain.

\section{TINJAUAN PUSTAKA}

\section{Metode Sekuensial Linier}

Pengembangan sistem informasi geografis ini menggunakan metode waterfall. Dari metode ini terdapat enam fase dalam pengembangan sistem. Model waterfall lebih cocok untuk sistem atau perangkat lunak yang bersifat generik, artinya sistem dapat diidentifikasi semua kebutuhannya dari awal dengan spesifikasi yang umum dan memiliki tujuan untuk membangun sebuah sistem dari awal yang mengumpulkan kebutuhan sistem yang dibangun sesuai dengan topik penelitian yang dipilih sampai dengan produk tersebut diuji.

Tahapan penelitian yang dilakukan mengikuti tahapan waterfall seperti yang terlihat pada gambar 2, yaitu terdiri dari analisis, desain, code dan pengujian. 


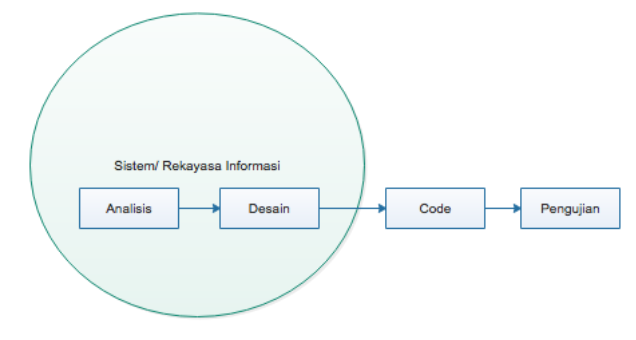

Gambar 2. Ilustrasi Model Sekuensial Linier

JavaScript

Menurut Robbins, J.N, (2012), "JavaScript merupakan bahasa pemrograman yang digunakan untuk menambah interaktivitas dan perilaku dalam suatu halaman web. Javascript juga digunakan untuk memanipulasi elemen pada halaman web, termasuk memanipulasi style bahkan penjelajah web itu sendiri".

JavaScript dapat berkolaborasi dengan HTML dan CSS, sehingga dapat mebuat halaman web menjadi semakin optimal. JavaScript merupakan bahasa yang bersifat client-side scripting, yang berarti proses yang dijalankan pada sisi pengguna dan dijalankan secara lokal oleh penjelajah web. Proses tersebut sangat efektif dan efisien karena proses yang dilakukan bersifat lokal sehingga tidak perlu melakukan request ke sisi server untuk menjalankan suatu perintah atau proses. Disamping itu server akan menjadi lebih ringan karena JavaScript dapat menghemat bandwidth dan beban dari server.

\section{Node.JS}

Menurut Ben. W (2013), "Node.js merupakan runtime environtment yang digunakan untuk membangun aplikasi web yang bersifat server-side". Node.js bersifat open-source dan juga cross- platform, sehingga dapat digunakan dengan mudah dan dapat beroperasi pada banyak platform atau sistem operasi meliputi FreeBSD, Linux, Microsoft Windows, OS $\mathrm{X}$, dan lain sebagainya.

Node.js menyediakan arsitektur yang bersifat even-driven dan non-blocking I/O API, sehingga membuat aplikasi menjadi ringan dan efisien (www.nodejs.org, 2018).
Menurut Orsini. L (2013), “Arsitektur berbasis event-driven yang dikombinasikan dengan arsitektur non-blocking I/O sangat cocok untuk membangun aplikasi dengan jumlah pengguna yang berjumlah jutaan. Komunikasi secara real-time akan ditangani oleh event-driven tanpa membutuhkan banyak memori, sehingga pengembang aplikasi dapat menghabiskan waktu lebih banyak untuk membangun fungsionalitas dari aplikasi".

\section{Express.JS}

Menurut Evan M.Han (2016). "Express.JS merupakan sebuah Node.JS framework yang berguna untuk mempermudah pembuatan aplikasi berbasis Node.JS dengan menggunakan design pattern yang dapat disesuaikan dan sangat fleksibel, selain itu Express.JS juga merupakan framework yang sangat ringan dan cocok untuk membuat web aplikasi dan API".

\section{MongoDB (NoSQL)}

Menurut Tiwari (2011), "MongoDB adalah sebuah document oriented database yang bersifat open source. MongoDB merupakan salah satu database NoSQL yang memiliki sebuah konsep penyimpanan data non-relational. Istilah NoSQL merupakan kepanjangan dari "Not Only SQL" yaitu sistem manajemen database yang berbeda dari sistem manajemen database rasional dalam beberapa cara. Penyimpanan data tanpa perlu adanya tabel schema dan tidak ada bahasa sql yang terlibat dalam pemakaian database.

\section{Google Maps API}

Menurut Svennerberg, Gabriel (2010), "Google Maps adalah sebuah layanan peta virtual gratis dan online yang disediakan oleh Google". Layanan ini dapat ditemukan di http://maps.google.com. Google Maps menawarkan peta seluruh dunia, dan juga menawarkan fitur perencanaan rute dan pencari lokasi bisnis di Amerika Serikat, Kanada, Jepang, Hong Kong, Cina, Inggris, Irlandia (hanya pusat kota) dan beberapa bagian Eropa. 
Menurut Svennerberg, Gabriel (2010), "Apllication Programing Interface (API) adalah antarmuka yang digunakan komponen software untuk saling berhubungan, sehingga bisa dikatakan Google Maps API itu berisi code atau script library untuk memanfaatkan fungsi Google Maps terutama pada halaman web yang kita buat apalagi berfungsi sebagai web komersil dan Google Maps sebagai fitur tambahan".

Tujuan dari penggunaan Google Maps API adalah untuk melihat lokasi, mencari alamat, dan mendapatkan petunjuk mengemudi".

\section{METODE PENELITIAN}

1. Subyek Penelitian

Subjek penelitian ini adalah "Pegaselastis Berbasis SIG Pada Jenjang SMA/SMK Kab. Sumedang.

Sedangkan sistem yang akan dibangun menginformasikan layanan tentang pemetaan guru jenjang SMA/SMK Kab. Sumedang. Sistem ini dibangun menggunakan beberapa software open source yaitu, Node.JS dan Express.JS yang merupakan server-side javascript web platform, MongoDB sebagai database storage, dan Google Maps API untuk implementasi peta digital.

2. Metode Pengumpulan Data

Dalam penelitian ini ada beberapa metode yang digunakan untuk mengumpulkan data dan bahan yang diinginkan yaitu :

a. Metode Observasi

Metode ini dilakukan dengan cara pengamatan langsung pada lokasi tempat penelitian yaitu Dinas Pendidikan Kabupaten Sumedang serta melakukan pencatatan dokumen yang berkaitan dengan obyek penelitian, seperti nama SMA dan SMK, nss, alamat, akreditasi, tahun berdiri, status sekolah, fasilitas, jumlah guru dan jumlah siswa.

\section{b. Studi Literatur}

Studi literatur adalah metode pengumpulan data dengan membaca buku referansi atau dokumentasi yang berhubungan dengan penelitian tentang sistem informasi geografis.
Dalam hal ini juga dilakukan browsing untuk mencari data atau dokumentasi yang berhubungan dengan obyek yang diteliti.

c. Metode Wawancara

Merupakan metode yang dilakukan dengan cara tanya jawab atau wawancara kepada Bapak Dr. Dian Sukmara, M.Pd. Selaku Kepala Bidang Pendidikan Menengah di Dinas Pendidikan kabupaten Sumedang bagian perencanaan yang mempunyai kapasitas dan informasi yang dibutuhkan dalam pelaksanaan penelitian ini.

\section{DESAIN SISTEM}

Arsitektur Aplikasi

Arsitektur aplikasi dapat digambarkan sebagai berikut :

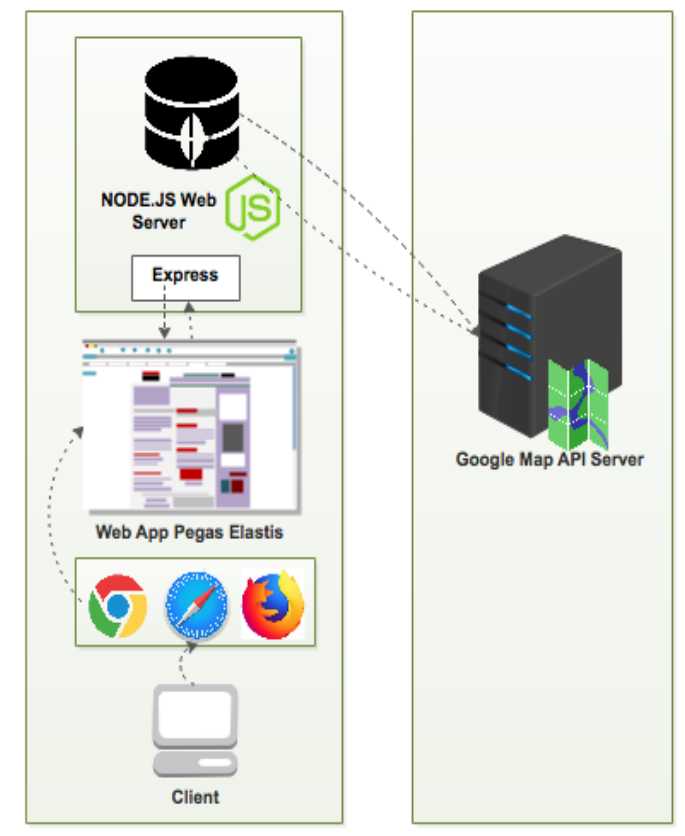

Gambar 3. Ilustrasi Arsitektur Aplikasi

Gambar 3 menunjukkan illustrasi arsitektur dalam pembuatan aplikasi web Pegas Elastis. Express.Js dan MongoLab merupakan 2 module yang terdapat di dalam server Node.Js.

Express.Js berfungsi sebagai penghubung antara RESTful web service dan Node.Js. Mongoose adalah module Node.Js yang berfungsi sebagai object data mapper pada MongoDb yang yang terhubung dengan 
google map api. Sedangkan web app pegas elastis adah sebuah front-end yang di kembangkan dengan meggnakan bahasa JavaScript.

\section{Flowchart Sistem}

Flowchart sistem dapat digambarkan sebagai berikut :

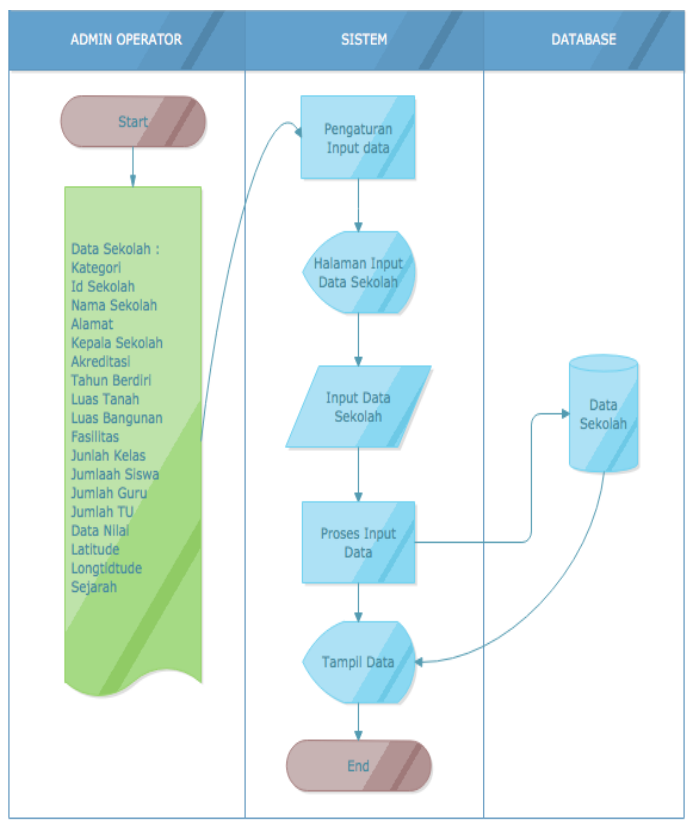

Gambar 4. Flowchart Sistem

Gambar 4 menjelaskan, bahwa pada proses Admin dimulai dari berkas data sekolah yang akan diinputkan ke dalam pengaturan Admin yang sudah login kemudian akan ditampilkan ke halaman input data kemudian data sekolah tersebut akan tersimpan ke dalam Database.

\section{HASIL DAN PEMBAHASAN}

Implementasi ini menjelaskan tampilan apa saja yang ada di aplikasi Pegas Elastis berbasis SIG. Berikut merupakan screenshot web app Pegas Elastis.

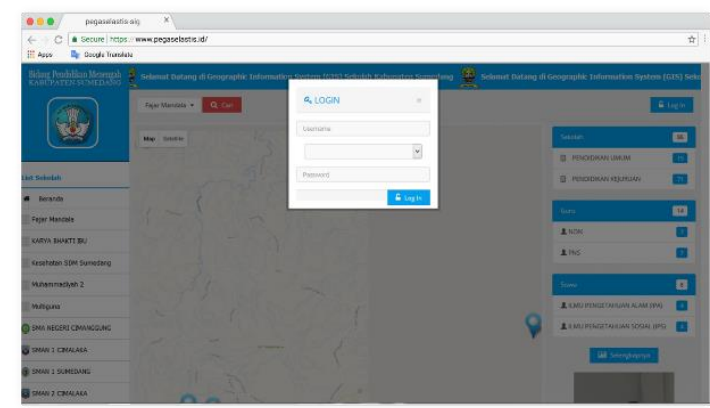

Gambar 5. Tampilan Login Pegas Elastis SIG

Gambar 5 merupakan tampilan Login Pegas Elastis SIG yang berisikan dengan nama-nama sekolah.

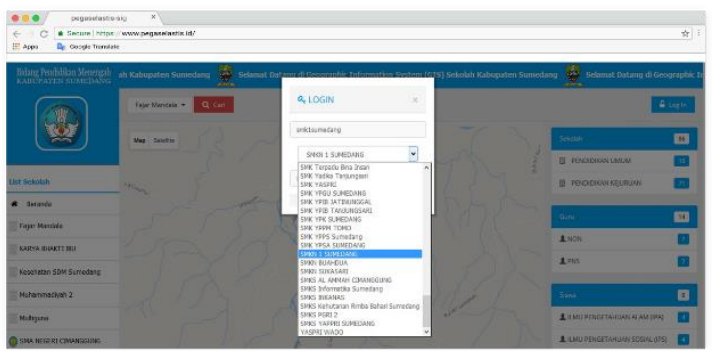

Gambar 6. Tampilan Login yang berisikan nama sekolah

Gambar 5 dan 6 merupakan tampilan awal login Pegas Elastis SIG, nama-nama sekolah jenjang SMA/SMK di wilayah Kab. Sumedang akan muncul setelah admin dari operator sekolah terkait memilih salah satu nama sekolah dari satuan pendidikan tersebut.

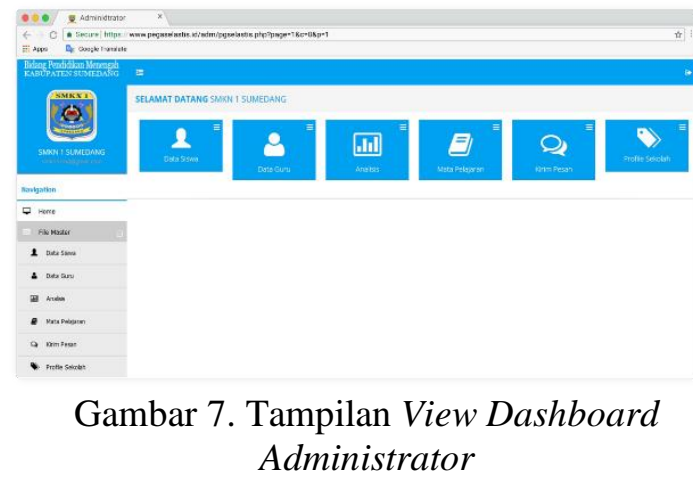

Gambar 7 merupakan halaman dashboard bagian Admin operator sekolah dari setiap satuan pendidikan untuk menginput, simpan, hapus dan ubah data sekolah jenjang SMA/SMK wilayah Kab. Sumedang yang 
meliputi file master, data guru, analilis, mata pelajaran dll.

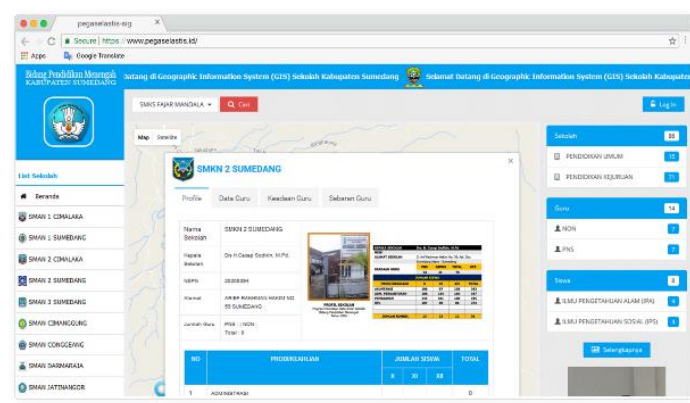

Gambar 8. Tampilan Pop Up Informasi Sekolah

Gambar 8 merupakan tampilan utama Pegas Elastis SIG setelah user memilih salah satu sekolah berdasarkan marker lokasi peta wilayah kab. Sumedang atau list sekolah di menu navigasi, akan muncul popup yang berisikan informasi sekolah seperti profil, data guru, keadaan guru, sebaran guru dan jumlah rombel siswa sesuai prodi/keahlian.

\section{KESIMPULAN DAN SARAN}

\section{Kesimpulan}

Berdasarkan penelitian yang telah dilakukan maka dapat disimpulkan sistem yang dibangun berupa Sistem Informasi Geografis berbasis web dapat berjalan dengan baik, selain itu pegas elastis berbasis SIG ini dilengkapi informasi yang berhubungan dengan sekolah setempat. Informasi yang disajikan berupa titik kordinat dengan pemanfaatan geolocation, profil, data guru, keadaan guru, sebaran guru dan jumlah rombel siswa sesuai prodi/keahlian. Dengan media web aplikasi ini memungkinkan para pengguna untuk mengetahui dan mencari informasi sekolah jenjang SMA/SMK di wilayah Kab. Sumedang yang dapat diakses dengan mudah secara online.

\section{Saran}

Sistem informasi ini sangat bermanfaat khususnya bagi kami guru dalam memenuhi target kewajiban mengajar sesuai dengan aturan yang berlaku. Dan mohon update dapat di akses oleh semua guru dalam berbagai jenis jenjang pendidikan.

\section{DAFTAR FUSTAKA}

Achmad Solichin, (2016), "Pemrograman Web Dengan Php Dan Mysql", Hal 10

Casciaro, Mario. (2014), "Node.js Design Patterns"

Evan M, Hahn. (2016). "Express in Action Writing", building, and testing Node.js applications

Prahasta, Eddy. (2001), "Konsep-konsep Dasar Sistem Informasi Geografis", Bandung: Informatika.

Svennerberg, G. (2010), "Beginning Google Maps API 3". United States of America $\therefore$ Apress

Tiwari, S. (2011), "Professional NoSQL. Indianapolis: John Wiley \& Sons, Inc. 